\title{
Revisiting Procedure and Precedent in the WTO: An Analysis of US - Countervailing and Anti-Dumping Measures (China)
}

\author{
MOSTAFA BESHKAR* \\ Indiana University \\ ADAM S. CHILTON** \\ University of Chicago Law School
}

\begin{abstract}
After not applying countervailing duty (CVD) law against non-market economies (NMEs) for two decades, the United States opened a CVD investigation against China in 2006. After extensive litigation, a US appeals court ruled that it was illegal to apply CVD law to NMEs. While that ruling was being appealed, the US Congress passed legislation stipulating that the application of CVD law to NMEs starting in 2006 was legal. China challenged this legislation at the WTO. The dispute resulted in a ruling that left open the possibility that the legislation violated the GATT, as well as a finding that the United States must investigate its application of countervailing and antidumping duties against China. This dispute has implications for a number of current WTO debates including: whether Appellate Body rulings create a binding precedent, whether the Appellate Body should have authority to remand cases, and what information should be required in panel requests.
\end{abstract}

\section{Introduction}

In the early 1980s, the United States Department of Commerce (USDOC) decided that it would not apply countervailing duty (CVD) law to Non-Market Economies (NMEs). In 2006, however, the USDOC reversed course and decided to open a CVD investigation against China despite its status as an NME country. This decision was challenged by China in the WTO, ${ }^{1}$ as well as by Chinese exporters in US courts. In 2012, the US Court of Appeals for the Federal Circuit ruled that the

\footnotetext{
* Email: mbeshkar@indiana.edu

**Email: adamchilton@uchicago.edu

We would like to thank the participants in the WTO Case Law conference at the European University Institute on May 13-14, 2015 for their helpful comments. We would also like to thank Katie Bass, ByeongHwa Choi, John Holler, and Arielle Knudsen for helpful research assistance.

1 The United States' 2006 decision to start applying CVD law to China was the subject of The United States' 2006 decision to start applying CVD law to China was the subject of United States - Countervailing and Anti-Dumping Measures on Certain Products from China, WT/DS449 [US-Countervailing and AntiDumping Measures (China)].
} 
USDOC's decision to apply CVD law to Chinese products was inconsistent with existing US trade law. Before this decision was final, however, the US Congress passed a law - known as the GPX Legislation ${ }^{2}$ - stating that CVD law is applicable to NMEs. Moreover, the law further stated that CVD law was applicable to NMEs starting in 2006.

In US-Countervailing and Anti-Dumping Measures (China), China challenged the GPX Legislation's retroactive clarification that US law permitted the application of CVD laws to NMEs. China specifically argued that the GPX Legislation was inconsistent with three of the requirements in Article X of the GATT on the publication and administration of trade agreements: (1) the requirement to publish laws promptly after they are made effective; (2) the requirement to not advance rates prior to their publication; and (3) the requirement to have agencies implement the decisions of tribunals reviewing trade policies. China additionally argued that the United States violated the Agreement on Subsidies and Countervailing Measures (SCM Agreement) by failing to investigate the simultaneous application of countervailing duties and antidumping duties - a practice known as applying 'double remedies' - in 26 cases between 2006 and the passage of the GPX Legislation in 2012.

In response to China's GATT claims, the United States argued against China's characterization of the GPX Legislation and interpretation of Article X. In response to China's SCM Agreement claims, the United States advanced two different lines of argument. First, the United States argued that previous WTO Appellate Body $(\mathrm{AB})$ precedents do not bind the panel, and that it should ignore a previous AB interpretation of the SCM Agreement Article 19.3 that established a duty to investigate the simultaneous application of countervailing duties and antidumping duties. Second, the United States argued that China's request for the formation of a panel was inconsistent with the requirements of the Dispute Settlement Understanding (DSU) because it listed several articles that the US allegedly violated without correctly specifying the correct sub-article at issue in the case.

The panel rejected all three of China's claims that the GPX Legislation was inconsistent with Article X of the GATT. The panel did, however, rule in favor of China's claim that the United States' failure to investigate the application of double remedies was inconsistent with US obligations under the SCM Agreement. In doing so, the panel did not accept the United States invitation to ignore the $\mathrm{AB}$ precedent or the argument that China's panel request was deficient.

China and the United States both appealed parts of the panel report. The AB overruled the panel's interpretation of one part of Article X of the GATT, and ruled that the GPX Legislation may have advanced rates prior to their publication. The $\mathrm{AB}$ was not able to complete the analysis and make a final ruling on whether the GPX Legislation violated Article X, however, because more information on the 
exact status of the US law prior to the passage of the GPX Legislation was required. Additionally, the AB rejected the United States' argument that China's panel request was deficient because it failed to specifically identify which aspects of the SCM Agreement had been violated. The AB instead ruled that the panel request was acceptable because it was possible to identify the relevant portions of the SCM based on the narrative of China's complaint.

Ultimately, the direct consequences of this dispute are limited: the United States will have to investigate the application of double remedies in a couple of dozen cases between 2006 and 2012. The issues raised by this dispute, however, speak to several important potential reforms of the WTO dispute settlement process. In this paper, we discuss five issues raised by the dispute. First, we consider whether a strong conception of vertical precedent - that is, $\mathrm{AB}$ rulings binding future panels - is desirable within the WTO. Second, we revisit the debate over whether the $\mathrm{AB}$ should be given authority to remand disputes back to panels. Third, we discuss the implications of allowing complaining states to file panel requests without specifically identifying the relevant articles that form the legal basis for their claim. Fourth, we explain how the AB's ruling may force future panels to engage with the legal decisions and procedures of the domestic court in a way that they previous have not had to do. Finally, we evaluate the validity of the AB's arguments on the application of double remedies.

\section{Background to the dispute}

The United States Department of Commerce (USDOC) decided during the early 1980s that it would not apply countervailing duty (CVD) law to Non-Market Economies (NMEs). This decision was made after the USDOC determined that it would be impossible to identify government financial contributions to producers in countries in which the governments were involved extensively in the economy. The USDOC's decision not to apply countervailing duty law to NMEs was challenged in US domestic courts. In a 1986 case, Georgetown Steel v. United States, the US Court of Appeals for the Federal Circuit affirmed the legality of the USDOC's policy of not applying CVD law to NME countries. ${ }^{3}$

For the next 20 years, the USDOC maintained its policy of not applying CVD law to NME countries. In 2006, however, that policy was revisited. In October of that year, the USDOC received a petition to initiate an investigation on Coated Free Sheet Paper imported from China. The USDOC notified China of its intention to accept the petition, and entered into consultations with China. The USDOC also publically announced that it was considering applying CVD law to China and invited comments on whether China warranted the application of CVD law despite being an NME. In 2007, the USDOC published a notice in the 
US Federal Register that it had 'determine[d] that the countervailing duty law can be applied to imports from the PRC'. ${ }^{4}$ This decision was justified based on the view that, unlike the soviet-style economies considered in Georgetown Steel, it was no longer impossible to apply CVD law to China because the modern Chinese economy includes a great deal of private ownership and entrepreneurship. As a result, it was decided that it would be possible to determine whether the Chinese government was subsidizing specific exports.

Following this change in policy, the USDOC began to initiate CVD investigations against China. After the USDOC conducted parallel CVD and AD investigations on certain off-the-road tires from China that resulted in the imposition of countervailing duties and antidumping duties in 2008, Chinese exporters filed complaints in the US court challenging the imposition of CVDs against countries classified as NMEs. This resulted in a series of cases known as the 'GPX Litigation'. These cases led to a 2011 ruling from the US Court of Appeals for the Federal Circuit that, contrary to the USDOC's 2007 decision, under existing US law 'countervailing duties cannot be applied to goods from NME countries'. ${ }^{5}$

The US Government responded to this decision by filing a petition for rehearing in March 2012. A week later, and before the court ruled on the petition for rehearing, the US Congress passed a law that has become known as the GPX Legislation'. ${ }^{6}$ This law overturned the previous court decision by explicitly noting that CVD law can be applied to NMEs. Moreover, the GPX Legislation further stated that this section of the law applies to all CVD investigations initiated 'on or after November 20, 2006'. In May of 2012, the US Court of Appeals for the Federal Circuit issued an order recognizing that Congress had overturned their previous decision and noting that this decision was made prior to the case being final because the petition for rehearing was still pending. ${ }^{7}$

In September of 2012, China filed a request for a consultation at the WTO, claiming that the GPX Legislation violated Article X of the GATT and that the United States failed to avoid the application of double remedies in 26 investigations initiated between 20 November 2006 and 13 March 2012. ${ }^{8}$

\section{Key issues examined in the panel and $A B$ reports}

After China dropped a number of claims during the panel proceeding, there were three remaining legal issues in US-Countervailing and Anti-Dumping Measures (China). First, China claimed that the GPX Legislation violated three parts of

4 Coated Free Sheet Paper from the People's Republic of China: Amended Affirmative Preliminary Countervailing Duty Determination, 72 Fed. Reg. 17,484, 17,486 (Department of Commerce, 9 April 2007).

5 GPX Int'l Tire Corp v. United States, 666 F.3d 732, 745 (2011).

6 United States Public Law No. 112-99, 126 Stat. 265 (13 March 2012).

7 GPX Int'l Tire Corp v. United States, 678 F.3d 1308 (2012).

8 US-Countervailing and Anti-Dumping Measures (China). 
Article X of the GATT. Second, China claimed that the United States' failure to avoid the application of double remedies in 26 investigations violated the SCM Agreement. Third, the United States challenged the consistency of China's panel request with the requirement that parties must provide a brief summary of the legal basis of their claim.

\subsection{Publication and administration of trade agreements}

China challenged the GPX Legislation's compliance with three different parts of the requirements in Article X of the GATT on the publication and administration of trade agreements. Those are the requirements in: (1) Article X:1 to publish laws promptly after they are made effective; (2) Article X:2 to not advance rates prior to their publication; and (3) Article X:3(b) to have agencies implement the decisions of tribunals reviewing trade policies.

\subsubsection{Publishing promptly}

China challenged the GPX Legislation's compliance with the requirement in Article $\mathrm{X}: 1$ of the GATT that measures be published promptly. The relevant part of Article $\mathrm{X}: 1$ requires that ' $[1]$ aws ... of general application, made effective by any [Member], pertaining to rates of duty, taxes or other charges, or to requirements, restrictions or prohibitions on imports ... shall be published promptly in such a manner as to enable governments and traders to become aquatinted with them'.

China's argument was that the GPX Legislation was inconsistent with this requirement because even though the legislation was enacted on 13 March 2012, the legislation was 'made effective' as of 20 November 2006. This is because Section 1 of the GPX Legislation clarified that CVD law can be applied to NMEs after 20 November 2006. China argued that the effective date of a law is "when it could have an actual effect "in practice", not the date on which it was formally promulgated or formally entered into force'. 9 The United States argued in response that 'made effective' clause 'is aimed at limiting the application of Article $\mathrm{X}: 1$ to measures that have been adopted or brought into operation' ${ }^{10}$

The panel agreed with the United States' interpretation of Article X:1, and argued that China's interpretation would render a range of measures that apply to events or circumstances before their entry into force inconsistent with Article $\mathrm{X}: 1 .{ }^{11}$ For example, China's interpretation would mean that legal or administrative rulings that impose legal consequences on past events were inconsistent with the GATT. The panel thus concluded that the GPX Legislation was made effective on 13 March 2012 and published promptly afterwards. China did not appeal this ruling to the $\mathrm{AB}$. 


\subsubsection{Advancing rates}

China challenged the GPX Legislation's compliance with the requirement in Article X:2 of the GATT that measures should not advance rates before being officially published. In relevant part, Article X:2 provides that 'No measures of general application ... effecting an advance in a rate of duty ... or imposing a new or more burdensome requirement ... shall be enforced before such measure has been officially published'. The article has been interpreted as having two elements. Successful claims must prove that a measure results in: (1) the advance or imposition of new or more burdensome requirements (2) that are enforced prior to publication.

China argued at the panel stage that since the GPX Legislation was passed in 2012 but allowed for CVD law to be applied to NMEs starting in 2006, the law advanced or imposed a new requirement before the law was officially published. ${ }^{12}$ The United States responded by arguing that the GPX Legislation not only did not advance the rates of duties or impose new burdens because the law simply codified the existing USDOC practice, but also that the GPX Legislation does not fall under the scope of Article X:2 because the legislation is not a measure of 'general application'. ${ }^{13}$

The panel first considered the second element of Article X:2, and found that the GPX Legislation was in fact enforced prior to publication. ${ }^{14}$ This is because the purpose of the GPX Legislation was to clarify that CVD Law applies to NMEs, and that the legislation established that this could be enforced prior to the legislation's publication in 2012. ${ }^{15}$ Next, the panel considered the first element of Article $\mathrm{X}: 2$ and found that to determine whether there had been an advance in a rate there must be a comparison 'between the new rate effected by the measure at issue and the rate that was previously applicable under an established and uniform practice'. ${ }^{16}$ The panel applied this interpretation of Article X:2 to find that the GPX Legislation was not an advance in rate because the USDOC started applying CVD law to NMEs in 2006. ${ }^{17}$

12 Ibid., para. 7.91 .

13 Ibid., para. 7.92 .

14 Ibid., para. 7.127.

15 In addition to this analysis, the panel also considered whether the GPX Legislation is a measure of 'general application'. The Panel found that the definition of 'general application' should be the same for Article X:1 and Article X:2. US-Countervailing and Anti-Dumping Measures (China), para. 7.137. This lead the Panel to reach the conclusion that the GPX Legislation is of general applicability despite being narrow in scope because it applies to an entire class of entities. Ibid., para. 7.35.

16 Panel Report, US-Countervailing and Anti-Dumping Measures (China), para. 7.155.

17 It is worth noting that there was a dissenting opinion on this point. Ibid., paras. 7.212-7.248. A Panelist writing in dissent argued that the appropriate standard to determine whether a measure had advanced a rate of duty in violation of GATT Article X:2 should be what the rate would have been in the absence in the measure. Ibid., para. 7.229. Under this standard, prior to the passage of the GPX Legislation, US law would not allow the application of CVD law to NMEs following the GPX 
China appealed this ruling to the $\mathrm{AB}$. The $\mathrm{AB}$ reversed the panel's interpretation of how to evaluate whether an advance in a rate had occurred under Article X:2. The $\mathrm{AB}$ argued that instead of comparing the new measure with the prior 'established and uniform practice', the correct comparison is between the new measure and the 'prior published practice'. ${ }^{18}$ The $\mathrm{AB}$ reasoned that this is the correct interpretation because Article X:2 reflects the principles of transparency and due process, and published measures are necessary to advance these goals.

Using this interpretation of Article $\mathrm{X}: 2$, the $\mathrm{AB}$ considered whether the GPX Legislation was an advance over the prior published measures in the United States or merely a clarification of them. Although the AB reviewed the history of the GPX Legislation at length, the $\mathrm{AB}$ ultimately determined that it was unable to complete the analysis because the panel had not adequately considered how to evaluate the legality of the USDOC's practice of applying CVD law to NMEs after 2006 and the legal status of the relevant judicial pronouncements. ${ }^{19}$

\subsubsection{Amending the law 'retroactively'}

China challenged the GPX Legislation's compliance with the requirement in Article X:3(b) of the GATT to implement judicial decisions. The relevant sections of Article X:3(b) provide that each Member 'shall maintain ... judicial ... tribunals' and that '[s]uch tribunals or procedures shall be independent of the agencies entrusted with administrated enforcement and their decisions shall be implemented by ... such agencies' unless an appeal is made.

China argued that the GPX Legislation was inconsistent with Article X:3(b) because the legislation amends the law retroactively and makes it applicable to judicial proceedings. China specifically argued that although 'the national legislature may enact new laws, and nation courts may be required to interpret and apply those laws in future cases', 'any such law must apply prospectively, and may not have the effect of altering the outcome of a judicial decision that was based on the laws in effect at the time the relevant administrative actions were taken' ${ }^{20}$ In response, the United States argued that Article X:3(b) does not impose any limits on national legislatures, and that Article X:3(b) instead imposes a 'structural' obligation on members to establish tribunals whose final decisions should be implemented by the relevant agencies. ${ }^{21}$

The panel agreed with the United States' argument that Article X:3(b) does not prohibit a member's legislature from passing a law like the GPX Legislation. The

Litigation. As a result, the panelist argued that the GPX Legislation should be ruled inconsistent with Article X:2 of the GATT.

18 AB Report, US-Countervailing and Anti-Dumping Measures (China), paras. 4.103-4.114.

19 Ibid., paras. 4.182-4.183.

20 Panel Report, US-Countervailing and Anti-Dumping Measures (China), para. 7.272.

21 Ibid., para. 7.246. The United States also argued that China's claim should fail because the litigation in question was not 'final' by the time the GPX Legislation was passed. 
panel's reasoning was in part based on the argument that X:2 regulates the passage of new legislation and that X:3 does not address the topic. ${ }^{22}$ As a result, it would be a mistake to read X:3(b) as applying a constraint on the ability of a member's legislature to pass a law like the GPX Legislation. Finally, the panel argued that it was unnecessary to resolve whether the obligation in $\mathrm{X}: 3(\mathrm{~b})$ was structural because it would not affect their overall conclusion that the GPX Legislation was not inconsistent with the article. ${ }^{23}$ China did not appeal this ruling to the AB.

\subsection{Failure to investigate double remedies}

China argued that the United States violated the SCM Agreement by failing to investigate whether remedies were imposed during 26 parallel CVD and AD investigations that were initiated between 20 November 2006 and 13 March 2012. ${ }^{24}$ China's claim relied on the AB's ruling in US-Countervailing and Anti-Dumping Measures (China) that imposing both CVDs and ADs calculated using an NME Methodology is inconsistent with Article 19.3 of the SCM Agreement, and that the burden is on the investigating authority to investigate whether the same subsidies are being offset twice. ${ }^{25}$ China argued that the United States had not complied with this ruling because the USDOC failed to investigate whether their simultaneous imposition of CVDs and ADs were based on the same underlying subsidies.

The United States objected to the interpretation of Article 19.3 that had been adopted by the $\mathrm{AB}$ in US-Countervailing and Anti-Dumping Measures (China). The United States argued that the $\mathrm{AB}$ erred when it found a duty to investigate in Article 19.3 of the SCM Agreement, and that the AB based its decision on arguments that were 'far afield' from the arguments made by the United States and China in DS379. ${ }^{26}$ Moreover, the United States argued that the panel was not obligated to adopt the same interpretation of Article 19.3 that the AB adopted in USCountervailing and Anti-Dumping Measures (China). Instead, the United States argued that panels are not bound to follow prior $\mathrm{AB}$ precedent when the findings are not persuasive or based on a valid understanding of the relevant agreements. As a result, the United States urged the panel to reject China's claim that the United States failed to comply with Article 19.3 by not investigating whether double remedies had been levied in parallel CVD and AD proceedings.

The panel rejected the United States request that it reconsider the interpretation of Article 19.3 that the $\mathrm{AB}$ had adopted in US-Countervailing and Anti-Dumping Measures (China). The panel acknowledged that, absent a 'cogent reason', it

22 Ibid., paras. 7.269-7.274.

23 Ibid., para. 7.296.

24 China initially argued that the United States had failed to investigate the application of double remedies in 26 proceedings, but the Panel found that the evidence suggested that the last investigation was initiated after 13 March 2012. Ibid., paras. 7.367-7.372.

25 Ibid., para. 7.308.

26 Ibid., para. 7.312 . 
should resolve legal questions the same way that they had been decided in previous AB decisions. ${ }^{27}$ The panel noted, however, that what constitutes a 'cogent reasons' to depart from prior interpretations had not previously been defined by the AB. Since the AB had not previously done so, the panel offered a list of four situations where a panel would have a cogent reason to ignore prior $\mathrm{AB}$ interpretations:

(i) a multilateral interpretation of a provision of the covered agreements under Article IX:2 of the WTO Agreement that departs from a prior Appellate Body interpretation; (ii) a demonstration that a prior Appellate Body interpretation proved to be unworkable in a particular set of circumstances falling within the scope of the relevant obligation at issue; (iii) a demonstration that the Appellate Body's prior interpretation leads to a conflict with another provision of a covered agreement that was not raised before the Appellate Body; or (iv) a demonstration that the Appellate Body's interpretation was based on a factually incorrect premise. ${ }^{28}$

The panel decided that none of these four reasons was present in this dispute and, as a result, that there was not a cogent reason to ignore the $\mathrm{AB}$ prior interpretation of Article 19.3. Based on this interpretation, the panel ruled that the United States had an obligation to investigate whether it had applied double remedies during the 25 concurrent CVD and AD investigations that the USDOC had conducted between 20 November 2006 and 13 March 2012. The panel further ruled that the evidence suggested that these investigations had not occurred and that consequently the United States had acted inconsistently with its obligations under the SCM Agreement. ${ }^{29}$ The United States did not appeal this ruling to the AB.

\subsection{Identification of specific measures within the panel request}

The United States argued that China's panel request did not meet the requirements of Article 6.2 of the Understanding on Rules and Procedures Governing the Settlement of Disputes (DSU). Among other things, Article 6.2 requires that requests to establish panels identify the specific measures at issue and provide a brief summary of the legal basis of the complaint sufficient to present the problem clearly'. This clause is read as containing two separate requirements, and the United States argued that China failed to meet the later requirement to identify the legal basis for the complaint.

Specifically, the United States argued that Part C and Part D of China's panel request did not clearly identify the legal basis of the complaint. The contents of Part D of China's request were central to this argument. In Part D, China claimed that the United States' failure to investigate and avoid double remedies in certain reviews between 20 November 2006 and 13 March 2012 were 
inconsistent with 'Articles 10, 15, 19, 21, and 32 of the SCM Agreement and Article VI of the GATT 19994'.30 The United States argued that prior AB rulings have indicated that panel requests alleging violations of articles with multiple paragraphs should identify the specific section of the article that is being violated. ${ }^{31}$ Additionally, the United States argued that inconsistencies with Article 6.2 must be evaluated based on the initial written submissions.

In a preliminary ruling, the panel determined that China's claim under Part $\mathrm{C}$ should be dropped and that only China's claims of violations of Articles 10, 19, and 32 of the SCM Agreement should be at issue. This was based on the panel's view that 'sufficiently clear inference' could be made that specific obligations at issue must be Articles 10,19.3, and 32.1. This is both because China specifically referred to 'double remedies' and referenced a previous WTO Dispute - USCountervailing and Anti-Dumping Measures (China) - that indicated that only those Articles could be at issue.

The United States appealed this ruling to the AB. The AB upheld the panel's finding that China's panel request was not inconsistent with Article 6.2 of the DSU. The AB did not directly adopt the panel's language of 'sufficiently clear inferences' when explaining why the information provided in China's panel request satisfied Article 6.2. Instead, the AB argued that the 'examination of all of the components of the panel request as a whole' and the 'content of the narrative explanation' make it possible to identify that references to Articles 10, 19, and 32 of the SCM Agreement actually refer to Articles 10, 19.3, and 32.1 of the SCM Agreement. ${ }^{32}$ Moreover, the AB rejected the United States' argument that China should not be able to cure its deficient panel request by dropping initial claims. The $\mathrm{AB}$ argued that abandonment of claims 'does not add to, or detract from, an independent assessment of whether the remaining claims are identified in a manner that is sufficient to present the problem clearly'. ${ }^{33}$

\section{Legal and economic analysis}

The direct consequence of the $\mathrm{AB}$ decision in US-Countervailing and AntiDumping Measures (China) is that the United States is required to investigate the simultaneous application of countervailing duties and antidumping duties in 25 cases that were initiated between 2006 and 2012. This dispute directly raises, however, several important issues about how the dispute settlement process should be structured. In this section, we discuss five of those issues.

$30 \mathrm{AB}$ Report, US-Countervailing and Anti-Dumping Measures (China), para. 4.18.

31 The United States specifically cited to China-Raw Materials to support this claim.

32 Ibid., para. 4.45 .

33 Ibid., para. 4.49 . 


\subsection{The role of precedent in the WTO}

One of the issues raised by US-Countervailing and Anti-Dumping Measures (China) is the status of precedent within the WTO dispute settlement system. As a de jure matter, the reports issued by panels and the $\mathrm{AB}$ are not binding precedents in future disputes. According to the WTO Legal Affairs Division and the Appellate Body Secretariat, '[e]ven if adopted, the reports of panels and the Appellate Body are not binding precedents for other disputes between the same parties on other matters or different parties on the same matter, even though the same questions of WTO law might arise. As in other areas of international law, there is no rule of stare decisis in WTO dispute settlement according to which previous rulings bind panels and the Appellate Body in subsequent cases. ${ }^{34}$ As a de facto matter, however, previous $\mathrm{AB}$ reports have been given significant persuasive authority. ${ }^{35}$

In fact, the $\mathrm{AB}$ itself has insisted that its decisions be treated as all but binding. In a previous dispute - US-Stainless Steel (Mexico) - the panel disagreed with an interpretation in a prior $\mathrm{AB}$ decision. ${ }^{36} \mathrm{In}$ response, the $\mathrm{AB}$ issued a report expressing 'deep concern' over the panel's decision not to follow the AB's prior interpretation. ${ }^{37}$ The $\mathrm{AB}$ went as far to say that ' $[\mathrm{t}]$ he Panel's failure to follow previously adopted Appellate Body reports addressing the same issues undermines the development of a coherent and predictable body of jurisprudence. ${ }^{38}$ The AB further argued that absent 'cogent reasons' the panel should resolve 'the same legal question the same way in a subsequent case'. ${ }^{39}$

What has not been clarified, however, is what constitutes a 'cogent reason' that would justify departing from a prior $\mathrm{AB}$ precedent. In US-Countervailing and AntiDumping Measures (China), the panel offered a set of four 'cogent reasons' that it believed would justify reaching a different conclusion than a prior $\mathrm{AB}$ decision. The panel specifically argued that it would be justifiable to ignore an $A B$ interpretation when it: (1) is contradicted by a new multilateral interpretation of the relevant agreement; (2) proven to be unworkable; (3) leads to a conflict with another agreement; or (4) is demonstrated to have been based on a factually incorrect premise. ${ }^{40}$

Although this definition of 'cogent reasons' does leave room to ignore a prior $\mathrm{AB}$ decision, it suggest that future panels should follow prior $A B$ interpretations even if they find legal arguments that reach a different conclusion more persuasive. The panel, however, did not provide any discussions beyond listing these 'cogent'

34 The legal effect of panel and appellate body reports and DSB recommendations and rulings is available at https://www.wto.org/english/tratop_e/dispu_e/disp_settlement_cb_e/c7s2p1_e.htm (accessed 5 May 2015). See also Gélinas (2006, 493).

35 Palmeter and Mavroidis (1998: 400-402); Bhala (1999: 849-50).

36 Panel Report, United States - Final Anti-Dumping Measures on Stainless Steel from Mexico, DS344, para. 7.115.

37 AB Report, US-Stainless Steel (Mexico), para. 162.

38 Ibid., para. 161.

39 Ibid., para. 160.

40 Panel Report, US-Countervailing and Anti-Dumping Measures (China), para. 7.317. 
reasons and, as a result, the scope of these conditions remains unclear. Moreover, the $\mathrm{AB}$ did not adopt this definition of cogent reasons, and it is unclear whether future panels will do so either. The issue of precedents in the WTO would have not been settled even if the $\mathrm{AB}$ had adopted these definitions of cogent reasons for when a prior ruling sets a precedent. That is because future litigants could claim that the AB's guidelines on precedents are not binding for future cases since $A B$ rulings do not have precedential value in the first place. With this line of reasoning, changing the way that precedents are treated in the WTO is beyond the authority of the Dispute Settlement Body (DSB).

Nevertheless, this case does raise the question of whether it is desirable for AB interpretations and rulings to be treated as binding precedents in all but a few narrow circumstances. There are obviously a number of benefits to affording $\mathrm{AB}$ decisions substantial precedential weight. Perhaps the primary benefit of treating AB interpretations as binding is that it may increase the legitimacy of the WTO dispute settlement system. If panels and the $\mathrm{AB}$ consistently reach the same conclusion when confronting the same legal issues, it suggests that the dispute settlement process is developing a stable system of law. Moreover, it also suggests that the same conclusion will be reached regardless of the parties. As a result, following prior decisions may lead to less criticism of both individual rulings as well as the system as a whole.

Another benefit of treating $\mathrm{AB}$ interpretations as binding is that it eliminates the need for costly litigation in the future when similar contingencies arise. That is because, given the precedent, the potential disputants can anticipate the DSB's ruling and, thus, a settlement will be achieved without litigation. In other words, the benefit of binding precedents in this setting is a reduction in the uncertainty about future DSB rulings. With binding precedents, the agreement evolves over time into a more comprehensive contract that identifies a greater number of contingencies and the associated rights and obligations.

There are, however, substantial costs to treating $\mathrm{AB}$ reports as binding precedents in future disputes. First, although precedents are expected to decrease the rate of disputes in the future by reducing the uncertainty of DSB ruling, attaching strong weight to precedents may initially lead to a higher frequency of litigation. That is because precedents increase the future stakes of the current dispute. The initial increase in the rate of litigation is more likely if the parties are repeatedly interacting over time or a particular contingency is likely to prevail again in the future. In a formal treatment of this issue, Maggi and Staiger (2011) show that the initial rise in the frequency of disputes and its associated costs could be large enough to exceed any benefits from uncertainty reduction.

Second, another downside of precedents is that a judicial mistake in one case will perpetuate over time. For example, Maggi and Staiger (2011) assume that the DSB has a mandate to maximize the joint welfare of the disputing parties. ${ }^{41}$

41 Ibid. 
Nevertheless, the DSB is likely unable to accurately compute the effect of policies on the joint welfare of the parties. Instead, the DSB observes only a noisy signal about the joint welfare of the parties as a function of trade policy. The observation that precedents increase the costs of erroneous DSB rulings does not necessarily imply that precedents are more desirable within an adjudication system that can evaluate the welfare-impact of different policies more accurately. In fact, Maggi and Staiger show that within their framework, precedents are welfare improving if the court is sufficiently inaccurate in evaluating the payoffs to the parties.

Third, giving $\mathrm{AB}$ reports strong precedential weight may increase the number of third party participants in disputes. If DSB rulings in a bilateral dispute set precedents that apply to all WTO members in the future, third parties will have a natural stake in the dispute. It is, therefore, expected that a binding precedent rule will increase the rate of third-party participation in WTO disputes. ${ }^{42}$ As reported by Beshkar and Majbouri (2015), United States and European Union each has participated as a third party to nearly $50 \%$ of cases in which they were not one of the primary disputing parties. This high rate of participation may reflect the desire of these countries to influence the development of substantive and procedural legal issues at the WTO. Moreover, third party participation in the panel procedure is likely to increase the overall cost of dispute settlement in the WTO. In addition to the costs of legal representation for the third parties, an increase in the number of interested parties in a dispute may diminish the prospect of reaching a mutually accepted resolution to the dispute in lieu of litigation. ${ }^{43}$

Fourth, treating $\mathrm{AB}$ reports as binding precedents raises a fairness issue with respect to developing countries. Large economies, especially the United States and the European Union, are by far the most frequent users of the dispute settlement system. This mechanism, therefore, has the potential to put smaller and poorer countries, which do not have the legal capacity to participate intensively in the system, at a disadvantage in the legal process. That is because larger actors in the system could develop the law through precedents in a way that serves their interests. What's more, this problem cannot be entirely solved by simply increasing the participation of developing countries within the WTO. This is because the AB has already issued a large number of interpretations on the covered agreements, and treating these interpretations as binding precedents ensures that rulings

42 According to the DSU, third parties can participate in the panel proceeding if they have a substantial interest in the case. In practice, if interested third parties invoke a 'systemic' interest in the dispute, they are admitted to the panel procedure without further scrutiny as to whether their interest in the case is substantial. The 'systemic' interest in a dispute may be interpreted as the concerns about the effect of DSB rulings on the substantive and procedural legal issues in the WTO, which may affect parties that are not directly involved in the current dispute.

43 There is no strong evidence in support of this argument. Busch and Reinhardt (2006) show that there is a negative correlation between the existence of third parties in a dispute and the likelihood of pre-trial settlement. However, Beshkar and Majbouri (2015) show that this correlation cannot be attributed to a causal effect of third parties on the rate of litigation. 
made while developing countries participation was more limited will continue to influence the outcome of disputes.

Fifth, treating $\mathrm{AB}$ interpretations as binding precedent is uniquely costly because it is almost impossible to change the covered agreements. In common law legal systems, judges are given the power to develop the law through the creation of binding precedent. If legislators disagree with a particular decision, they can change the relevant law to ensure that it will not continue to have an effect going forward. In fact, in some cases judges will explicitly invite legislators to pass new legislation if they disagree with a particular decision. Even though political realities may make it difficult for legislatures to change laws in response to particular decisions, the fact that it is at least possible helps to protect against decisions that are unpopular or based on poor reasoning. In the case of the WTO, the requirement of consensus makes it all but impossible to amend agreements to correct even the most egregious of legal decisions. As a result, the costs of precedent may be substantially higher in the WTO system than they are in almost all domestic settings.

To be clear, it is not our position that it is necessarily undesirable to have panels treat prior $\mathrm{AB}$ decisions as binding precedent. Instead, our argument is that USCountervailing and Anti-Dumping Measures (China) not only illustrates how the precedential status of $\mathrm{AB}$ decisions is still not settled to the satisfaction of all WTO members, but also illustrates that it is an issue that may be unresolvable within the DSB. Moreover, any re-evaluation of the status of precedent within the WTO should take into consideration the full range of costs and benefits of treating $\mathrm{AB}$ rulings as binding on future panels.

\subsection{Remand authority for the DSU}

Another issue that US-Countervailing and Anti-Dumping Measures (China) raises is whether the $\mathrm{AB}$ should have remand authority. ${ }^{44}$ Under current DSU rules, the $\mathrm{AB}$ is not able to engage in fact finding or to supplement the facts that are not in the record produced by the panel process. Instead, the $A B$ is only able to review the panel's legal analysis. ${ }^{45}$ The consequence is that when the $\mathrm{AB}$ overturns a panel's legal analysis-as it did in US-Countervailing and Anti-Dumping Measures (China) - there may not be enough information in the record to make a determination on how a specific issue should be resolved. In those cases, the $\mathrm{AB}$ has either been forced to 'complete the analysis' for the panel based on the available information, or the $\mathrm{AB}$ has had to decline to complete the analysis and leave the issue unresolved. ${ }^{46}$ Both of these approaches have considerable

44 This issue has previously received considerable attention by WTO Commentators. For an overview of the issue, see Pauwleyn (2007).

45 See DSU Article 17.6.

46 See, e.g., François and Palmeter (2008: 228). 
shortcomings. ${ }^{47}$ Given the significance of this problem, whether the AB should have remand authority has been a major subject in debates about reforming the WTO dispute settlement process. ${ }^{48}$

To date, commentators have focused on two sets of concerns: (1) the logistics of implementing remand authority and (2) the impact that remand authority would have on the length of disputes. First, the logistical concern with giving the AB remand authority is that currently panels are formed on an ad hoc basis. The panelists often have full-time jobs and travel to the WTO to participate in a specific dispute. ${ }^{49}$ As a result, it is possible that some - or even all - of the members of the original panel would not be available to participate in a remanded dispute. Implementing remand authority would thus require structuring the current panel system to either: (a) create a permanent body of panelists; (b) allow for new panelists to hear a case on remand; or (c) require prospective panelists to commit to hear a case even if it were remanded. All of these options have considerable costs associated with them, and it is not clear that there would be the political will to undertake any of them.

Second, there is a concern that implementing remand authority could have an impact on the length of disputes. One explanation put forward to account for the initial decision to not give the $\mathrm{AB}$ remand authority is that the drafters were 'concerned that remand could lead to matters bouncing endlessly back and forth between panels and the Appellate Body? ${ }^{50}$ Although it is certainly possible that disputes would bounce back and forth, it is not obvious that remand authority would result in longer disputes. Other commentators have argued that the lack of remand authority does not result in the swift resolution of disputes, but instead results in proceedings that stretch out over years. ${ }^{51}$

A consideration that has received less attention, however, is how the introduction of remand authority could change the behavior of litigants, panelists, and the AB. For example, panelists may be concerned that remanded cases would increase their workload or impact their reputation adversely. Such concerns may lead panelists to craft reports that are less likely to be reversed by the AB. In other words, introduction of the remand authority could induce the panelists to predict the $\mathrm{AB}$ rulings rather than developing their own independent assessment and interpretation of the case at hand. This could potentially reduce the overall DSB quality - two brains are better than one.

47 Pauwleyn (2007: 9-21).

48 Van den Bossche and Zdouc (2013: 303); Crowley and Palmeter (2009: 262); Lockhart and Voon (2005: 483).

49 Kingery (2000: 8-9).

50 Palmeter (1998: 43).

51 See, e.g., Iynedjian (2005: 817); Bahala and Attard (2003: 660). See also Janow and Staiger (2004: 314) ('Despite the absence of formal remand authority under the rules of the DSU, [Canada-Dairy] has already produced two 21.5 panels and three $\mathrm{AB}$ rulings'). 
Alternatively, panelists may be more willing to go out on a limb if they know that the $\mathrm{AB}$ can always send back reports that it wishes to be changed. Although the exact consequences are not clear, few discussions of the desirability of remand authority in the WTO have considered the dynamic consequences that it would have on the behavior of actors within the dispute settlement process. If the AB's decision to not complete the analysis in US-Countervailing and Anti-Dumping Measures (China) reignites the debate over remand authority, these issues should be considered more fully.

\subsection{Filing requirements for panel requests}

The United States argued at both the panel and AB stage that China's request for the formation of a panel was inconsistent with Article 6.2 of the DSU. The United States specifically argued that China failed to provide a 'brief summary of the legal basis of the complaint' because China's request included reference to several Articles of the DSU without clarifying which specific rules were being violated. The AB rejected the United States' claim by arguing that the text and narrative of China's claim made it clear which articles China specifically intended to reference. The AB's interpretation of Article 6.2 of the DSU - that context can be used to evaluate which specific articles complainants are basing their legal claims on - raises several important questions about litigation at the WTO.

Most directly, the AB's interpretation of Article 6.2 in US-Countervailing and Anti-Dumping Measures (China) creates the appearance of a double standard within the DSU. In China-Raw Materials, ${ }^{52}$ the United States, Mexico, and the EU argued that China had export restrictions on natural resources that were inconsistent with WTO rules. ${ }^{53}$ In that dispute, the AB threw out about half of the panel's rulings because the initial panel requests did not state the legal basis for the claims with sufficient specificity (Bronckers and Maskus 2014: 397-398). In other words, in China-Raw Materials the $\mathrm{AB}$ rejected claims brought against China by the United States for not being sufficiently specific, but then later the same year China was able to request a panel against the United States without making specific claims in its request. US-Countervailing and Anti-Dumping Measures (China) thus appears to indicate that the WTO is either retreating from its holding in China-Raw Materials or is perhaps willing to apply a lower standard to complaints filed by developing countries.

Setting aside the appearance of a double standard created by the AB's evolving interpretation of Article 6.2, it is worth considering the implications of allowing context to be used to evaluate which specific articles complainants are basing their legal claims on. This interpretation of Article 6.2 may have the direct effect

52 Reports of the Appellate Body, China - Measures Related to the Exportation of Various Raw Materials, WT/DS394.

53 See Bronckers and Maskus (2014) for a discussion of this dispute. 
of lowering initial costs to filing complaints at the WTO. By allowing for members to not precisely identify which articles they are relying on to make their arguments, members can file complaints while listing several relevant articles that likely cover the alleged violation. This may make it easier for members with less experience in the WTO system to file successful complaints. ${ }^{54}$ Lowering upfront costs for complainant states in this way may help to facilitate participation by developing states in the dispute settlement process.

The corollary to this benefit, however, is that lowering the initial filing costs for complainant states will also likely increase costs for the respondent states. By allowing members to list multiple articles that a measure allegedly violates before narrowing down the complaint through the course of the panel process, this interpretation of Article 6.2 may force respondents to have to prepare defenses against a larger number of potential claims. This will not only require respondents to expend resources preparing defenses against multiple articles that will ultimately not be part of the dispute, but if the respondents face resource constraints - like limited time or legal budgets - it may leave fewer resources to spend on the legal issues that ultimately are ruled to be relevant by the panel. Since developing states can be respondent states as well as complainant states, it is not clear that shifting these costs onto the respondents will help improve equity within the system.

Moreover, this interpretation of Article 6.2 will also increase the costs placed upon the dispute settlement system. The panelists will now be forced to engage in legal analysis to determine which sub-articles are relevant to the various arguments that complainants raise in their panel requests. This task will force both the panelists - and in turn the $\mathrm{AB}$ - to critically examine more arguments than they were previously required to in order to determine the legal basis for a given complaint. This not only increases the workload of the panelists, but also the discretion that they are afforded. This consequently may increase the uncertainty for parties to a given dispute.

Finally, it is worth noting that this interpretation of Article 6.2 not only lowers the costs for complainant states, but also increases the possibility for gamesmanship. Complainants may be able to strategically list multiple articles during their panel requests to both increase the costs for respondents, but also to increase the probability that they will make an argument that the panel finds persuasive. After all, part of the context that the panel will evaluate is whether a given argument is at all plausible for a given dispute. As a result, the complainant state may be able to both gain strategic advantage over the respondent state and also increase the probability that they will find an argument that is persuasive to the panelists.

54 This may also make it easier for countries with a great degree of familiarity with the WTO system to file complaints because it may require less upfront research on the specific articles to reference for particular claims. 


\subsection{Evaluating the status of municipal law}

A central issue in US-Countervailing and Anti-Dumping Measures (China) is whether the passage of the GPX Legislation was inconsistent with Article X:2 of the GATT because it imposed a new requirement before notice was published. As previously noted, in 2012 the US Court of Appeals for the Federal Circuit ruled that the application of CVD law to NMEs since 2006 had been inconsistent with US law. In response, the US Congress immediately passed the GPX Legislation, which stipulated that the application of CVD law to NMEs was legal under US law as of 2006. The question then is whether the GPX Legislation was merely a reiteration of existing US law or instead the imposition of a new requirement.

The panel ruled that the GPX Legislation was not an advancement of US law because the relevant baseline to compare the GPX Legislation to was the 'established uniform practice' of the government. ${ }^{55}$ Based on this interpretation, the panel found that, since the USDOC had been interpreting the application of CVD law to NMEs as consistent with US law since 2006, the GPX Legislation's stipulation in 2012 that applying CVD law to NMEs was consistent with US law was not a violation of Article X:2 of the GATT. The AB report, however, reversed this interpretation and argued that the relevant baseline is the "prior published practice'. ${ }^{56}$ Although the $\mathrm{AB}$ standard may seem straightforward, as USCountervailing and Anti-Dumping Measures (China) illustrates, determining exactly what the prior published law stands is not always easy.

The difficulty is that evaluating the 'prior published practice' requires interpreting what the relevant 'municipal law' was within the given jurisdiction. As the $\mathrm{AB}$ counseled, this determination should start with the text of the domestic law. ${ }^{57}$ Of course, the determination does not end with the text of the law. Instead, as the AB ruled, it will also require looking to the 'relevant practices of administering agencies' and examining 'the legal interpretation given by a domestic court'. ${ }^{58}$ Moreover, since agency practices and court decisions have different legal effects on the status of municipal law in different member states, the $\mathrm{AB}$ recognizes that this assessment will be based on the 'circumstances of each case, including the national legal system in which the municipal law operates'. ${ }^{59}$

This $\mathrm{AB}$ interpretation not only requires future panels to engage in more fact intensive inquiries generally, but it also specifically compels future panels to evaluate the content and legal status of domestic court rulings. Based on this interpretation of Article X:2 of the GATT, panels will have to examine how the interpretations

55 Panel Report, US-Countervailing and Anti-Dumping Measures (China), para. 7.155.

$56 \mathrm{AB}$ Report, US-Countervailing and Anti-Dumping Measures (China), paras. 4.103-4.114.

57 Ibid., para 4.101.

58 Ibid.

59 Ibid. 
made in court cases effect the legal status of the existing published laws on a topic. This $\mathrm{AB}$ ruling may thus have the effect of forcing panels to directly engage in the reasoning and procedures of domestic legal systems in a more intensive way than they previously have had to.

\subsection{Double remedies and NME Methodology}

One of China's claims in US-Countervailing and Anti-Dumping Measures (China) was that the United States failed to investigate and avoid the application of double remedies in 26 investigations initiated between 20 November 2006 and 13 March 2012. This claim directly follows from the legal issues addressed in China's prior challenge to the United States' application of CVD law after 2006 in USCountervailing and Anti-Dumping Measures (China).

In that dispute, one of the key issues was whether the simultaneous application of CVDs and ADs while using a non-market economy methodology ('NME Methodology') to calculate the true price of products necessarily results in 'double remedies'. Under the rules of the WTO, applying both an AD and a CVD to address an export subsidy is prohibited. ${ }^{60}$ This is because the difference between the domestic price and export price of a product would account for both the export subsidy and any dumping margin and, as a consequence, applying both CVDs and ADs simultaneously would result in double the necessary remedy. Simultaneously applying an $\mathrm{AD}$ and a CVD to address a domestic subsidy, however, can be permitted under WTO rules. This is because the difference between the domestic price and the export price would not fully capture the benefit of a subsidy that lowers domestic prices.

When a NME Methodology is used, however, the simultaneous application of CVDs and ADs almost necessarily results in a double remedy. This is because the NME Methodology does not rely on the actual domestic price within the exporting country to calculate either the dumping margin or domestic subsidy level, but instead uses prices from surrogate market economies to calculate the true market price of the product. The consequence is that the substitute price used by the NME Methodology should be the unsubsidized price. As a result, the difference between the price calculated using the NME Methodology and the export price should - almost always - account for any dumping margin and any subsidy. The implication is that there is thus no need to apply both CVDs and ADs simultaneously. ${ }^{61}$

60 See Article V1:5 of the GATT.

61 Prusa and Vermulst (2013) identify three cases caveats to general rule that the simultaneous application of CVDs and ADs will result in double remedies when a NME Methodology is used: (1) if the producers in surrogate countries are benefiting from the subsidy in the target country; (2) when the target country has such a dominate role in the market for a given product that they have depressed prices on the world market; and (3) when the subsidy in the target country lowers the profit rate in the surrogate 
In US-Countervailing and Anti-Dumping Measures (China), the AB did not use economic reasoning to explain why the simultaneous application of CVDs and ADs is almost guaranteed to result in the double remedies when a NME Methodology is used. Instead, the AB report ruled that double remedies are 'likely' to occur when CVDS are imposed concurrently with ADs under the United States' NME Methodology. ${ }^{62}$ As Prusa and Vermulst (2013) argue, however, this ruling opens the door for future $\mathrm{AB}$ cases addressing whether CVDs and ADs are acceptable in a given case, despite the fact double remedies are almost certain when an NME methodology like that of the United States is used. ${ }^{63}$ The claim raised by China in US-Countervailing and Anti-Dumping Measures (China) ${ }^{64}$ demonstrates that Prusa and Vermulst were correct. The panel ${ }^{65}$ simply reiterated the AB's ruling from US-Countervailing and Anti-Dumping Measures (China), 66 and, as a result, failed to close the door.

\section{Concluding comments}

In US-Countervailing and Anti-Dumping Measures (China), the AB ruled that the United States must investigate whether double remedies had been applied in 25 USDOC reviews of Chinese exports opened between 20 November 2006 and 13 March 2012. The relatively limited direct consequences of the dispute masks the range of important issues that this case speaks to. The arguments and analysis raised in US-Countervailing and Anti-Dumping Measures (China) may have implications for debates on the reforming the WTO for years to come.

\section{References}

Bhala, R. (1999), 'The Myth About Stare Decisis and International Trade Law', American University International Law Review, 14: 845-956.

— and L. Attard (2003), 'Austin's Ghost and DSU Reform', The International Lawyer, 37(3): 651-676. Beshkar, M. and M. Majbouri (2015), 'Estimating a Model of Settlement Bargaining in the WTO', Working Paper.

Bronckers, M. and K. E. Maskus (2014), 'China-Raw Materials: A Controversial Step Towards Evenhanded Exploitation of Natural Resources', World Trade Review, 13(2): 393-408.

Busch, M. L. and E. Reinhardt (2006), 'Three's a Crowd: Third Parties and WTO Dispute Settlement', World Politics, 58(3): 446-477.

Crowley, M. and D. Palmeter (2009), 'Japan-Countervailing Duties on Dynamic Random Access Memories from Korea (DS 336 and Corr.1, adopted 17 December 2007)', World Trade Review, 8(1): 259-272.

country in a way that is not captured by the NME methodology. Prusa and Vermulst argue, however, that these conditions are unlikely to be true in the case of US investigations of Chinese exports.

$62 \mathrm{AB}$ Report, US-AD and CVD (China), para. 602.

63 Prusa and Vermulst (2013), at 225.

64 US-Countervailing and Anti-Dumping Measures (China), DS449.

65 In ibid.

$66 \mathrm{AB}$ Report, US-Countervailing and Anti-Dumping Measures (China), DS379, para. 7.341. 
Francois, J. F. and D. Palmeter (2008), 'US - Countervailing Duty Investigation of DRAMS', World Trade Review, 7(1): 219-229.

Gélinas, F. (2006), 'Dispute Resolution as Institutionalization in International Trade and Information Technology', Fordham Law Review, 74: 489-504.

Iynedjian, M. (2005), 'Reform of the WTO Appeal Process', Journal of World Investment and Trade, 6: 809-840.

Janow, M. E. and R. W. Staiger (2004), 'Canada - Dairy Canada - Measures Affecting the Importation of Dairy Products and the Exportation of Milk', World Trade Review, 3(2): 277-315.

Kingery, J. (2000), 'Commentary: Operation of Dispute Settlement Panels', Law and Policy in International Business, 31: 665-673.

Lockhart, J. and T. Voon (2005), 'Reviewing Appellate Review in the WTO Dispute Settlement System', Melbourne Journal of International Law, 6: 474-484.

Maggi, G. and R. W. Staiger (2011), 'The Role of Dispute Settlement Procedures in International Trade Agreements', Quarterly Journal of Economics, 126(1): 475-515.

Palmeter, D. (1998), 'The WTO Appellate Body Needs Remand Authority', Journal of World Trade, 23: $41-44$.

— and P. C. Mavroidis (1998), 'The WTO Legal System: Sources of Law', American Journal of International Law, 92: 398-413.

Pauwleyn, J. (2007), 'Appeal Without Remand: A Design Flaw in the World Trade Organization Dispute Settlement and How to Fix it', ICTSD Dispute Settlement and Legal Aspects of International Trade Issue Paper, No. 1.

Prusa, T. J. and E. Vermulst (2013), 'United States - Definitive Anti-Dumping and Countervailing Duties on Certain Products from China: Passing the Buck on Pass-Through', World Trade Review, 12(2): 197-234.

Van den Bossche, P. and W. Zdouc (2013), The Law and Policy of the World Trade Organization, 3rd edn, Cambridge: Cambridge University Press. 